\title{
Practical experience with the implementation of a MOET breeding scheme with dairy cattle
}

\author{
WB Christie, BJ McGuirk, RJ Strahie, JS Mullan
}

\author{
Genus MOET Nucleus Herd, Bays Leap Farm, Heddon on the Wall, \\ Newcastle upon Tyne, NE15 OJW, UK
}

(Received 5 July 1991; accepted 5 September 1991)

\begin{abstract}
Summary - A nucleus breeding project is currently being developed with Holstein dairy cattle in the UK. The herd has been established by embryo transfer, with embryos collected from donor cows in North America and subsequently transferred in the UK. Since 1987, over 2000 embryos from 70 different donors have been transferred. The first 100 heifers are already milking and the herd will reach its mature size of 250 milking cows in 1992. Although the majority of donors will be selected from within the herd on overall economic merit, the herd will operate as an open nucleus, with continuing introductions of embryos, semen and probably live animals. In addition to describing the aims of the project and the evaluation and selection procedures, this paper will summarize embryo production results from donors in the US, as well as factors influencing pregnancy rates with embryo transfer.
\end{abstract}

MOET / cattle / embryo transfer / nucleus herd / pregnancy

Résumé - Utilisation du transfert d'embryons dans un noyau de sélection en bovins laitiers. Un projet de noyau de sélection est actuellement en cours de développement au Royaume Uni. Le troupeau a été fondé par transfert d'embryons collectés de vaches donneuses en Amérique du Nord et transférés ultérieurement au Royaume Uni. Depuis 1987, plus de 2000 embryons de 70 donneuses différentes ont été transférés. Les premières 100 génisses sont actuellement en lactation et le troupeau atteindra sa taille adulte de 250 vaches laitières en 1992 . Bien que la majorité des donneuses soit sélectionnées dans le troupeau sur leur mérite économique global, le troupeau sera géré en noyau ouvert, avec introduction continue d'embryons, de semence et probablement d'animaux vivants. En plus de la description des buts du projet et de l'évaluation des procédures de sélection, cet article résumera les résultats de production d'embryons des donneuses aux USA, ainsi que les facteurs qui influent sur la fertilité après transfert.

superovulation / bovin / sélection / gestation / transfert d'embryon 


\section{INTRODUCTION}

Over the past 30-40 yr, dairy cattle breeding schemes have been based on progeny testing. In that time, they have undergone continuing refinement and improvement. One area of improvement has been in the more satisfactory methods of analysing progeny test records, and continuing developments in this area can be expected. For example, with the animal model method of BLUP evaluation, information on all of the candidate's relatives can now be used. Advances in reproductive physiology have also had an impact. Thus in North America in particular, MOET (multiple ovulation and embryo transfer) has been used widely on prospective bull dams, so that fewer cows are now being used as bull mothers, and these are often also younger when their sons are born. At the same time, the basic structure of progeny testing schemes has remained.

Nicholas and Smith (1983) suggested that breeding schemes based entirely on the use of MOET in a nucleus herd could give faster genetic progress than is possible from progeny testing. While this prediction has now been modified, so that the theoretical (ie maximum) rates of progress for the 2 approaches are now thought to be similar, there are a number of reasons for believing that MOET may give faster progress in practice. These factors include the possibility of comparing cows under standard conditions, plus the potential for greater operational control over the programme.

Since the original paper by Nicholas and Smith (1983), various forms of breeding scheme using MOET have been proposed (Colleau and Mocquot, 1989). This paper will describe the implementation of an adult MOET nucleus scheme for Holstein Friesians, operated by Genus in the United Kingdom. This is the scheme estab- lished by Premier Breeders, a private company subsequently taken over by the Milk Marketing Board of England and Wales, the MMB. It will operate as an adult MOET, as described by Nicholas and Smith (1983), but with provision for the continuing introduction of suitable outside genetics, so that it might best be described as an "open nucleus". The first heifers in this scheme are now approaching the end of their first lactation. This paper will focus on embryo transfer results in the UK, together with information on embryo production from North American donor cows, used to produce foundation embryos for the scheme.

\section{HERD ESTABLISHMENT}

The aim of the Genus project is to establish and operate an adult MOET programme, based on a nucleus herd of 250 Holstein Friesian cows. The technical goal is to maximize the level of genetic merit for overall economic efficiency, so that the herd can then serve as a reliable source of top quality genetics, and thus meet its commercial objectives.

The Genus MOET nucleus herd has been established by embryo transfer. In the foundation phase (1987-1990 inclusive), the aim was to transfer 512 embryos per year, with 16 donor cows each contributing 32 embryos (table I). These embryos were expected to result in full sib families of 16,8 males and 8 females, and a total of 130 heifers per year. After operating such a transfer programme for $4 \mathrm{yr}$, we expected to produce our herd of 250 cows of only 2 age groups.

In the subsequent selection or "open nucleus" phase (1991 onwards), 32 donors should each contribute 16 embryos, so that we expect an average of 4 full sisters per family. However, there should also be 
Table I. Annual targets for embryo transfer in the MOET programme.

\section{Foundation Selection phase phase (1987-1990) (1991 onwards)}

\begin{tabular}{lrr} 
Donor cows & 16 & \\
Embryos per donor & 32 & 32 \\
Embryos transferred & 512 & 512 \\
Heifers & 130 & 130 \\
\hline
\end{tabular}

3 groups of 4 half-sisters (same sire, different dam), so that the accuracy of evaluation for MOET families in the two phases, and hence of bull selection, should be the same.

In order to ensure an immediate lift in genetic merit, it was decided to establish the herd from embryos imported from North America. Because of veterinary regulations, no embryos had been imported from the US into the UK before the start of the MOET project, which is some years after embryo importations commenced to other European countries, notably France and the Netherlands.

During the foundation phase, 70 different donor cows have contributed embryos to the scheme. All came from the top 3\% of either the US or Canadian populations for genetic merit for weight of fat plus protein, which was taken as the criterion of efficient dairy production. In addition, the cows had to be superior on type criteria. These donors were mated to a total of 24 service sires, all among the top North American proven bulls for weight of fat plus protein. Where donors were good embryo producers, they sometimes contributed a further family of full sib embryos, once their original quota of 32 embryos was met. Thus the 70 donors have to date contributed 89 different full sib families to the scheme.

\section{EMBRYO PRODUCTION AND PREGNANCY RATES}

Most of the donor cows involved in the programme have been taken to one commercial embryo collection centre, where the flushed embryos have been frozen and then transported to the UK. Almost all embryos (ie fertilized ova) collected were frozen and dispatched. In a sample of 1224 embryos collected from 37 donors, < 5\% $(62 / 1224)$ were not frozen. This fact is relevant when considering subsequent pregnancy rates.

Information on embryo production has also been summarized for 154 flushes from 36 adult donors of mixed ages, which were flushed over a 9-month period. There was no decline in embryo recovery over that time (table II). These flushes yielded 690 embryos, an average of 4.48 per flush, with a range of from 0-35 embryos per flush. Of these flushes, $21.4 \%$ yielded no embryos, while a further $37.7 \%$ yielded between 1 and 3 embryos.

The results obtained with US donor cows have been used to establish embryo production targets for UK donors in the selection phase of the project, when the plan is to transfer 16 embryos per donor (table I). With the US donors, there was wide variation in total embryos produced over a 9 -month flushing programme. Only $44 \%$ of

Table II. Average numbers of embryos produced from 36 donors repeat flushed over a 9month period.

$\begin{array}{ccc}\text { 1st } & \text { 2nd } & 3 \text { d } \\ 3 \text { months } & 3 \text { months } & 3 \text { months }\end{array}$

$\begin{array}{lccc}\text { No of flushes } & 56 & 46 & 52 \\ \text { No of embryos } & 265 & 186 & 239 \\ \text { Average per flush } & 4.7 & 4.0 & 4.6\end{array}$


donors yielding 16 or more total embryos for transfer in that time, with $77 \%$ producing 10 or more embryos. This suggests that we will have to flush more potential donors than originally planned, in order to produce the annual requirements for the scheme.

The first selected UK donors are currently in a repeat flushing programme. Initial concern that high yield, first lactation cows on a 3 times daily milking regime would prove poor donors, appear unfounded. To date 35 flushes have averaged 4.5 freezeable embryos, with $2 / 18$ donors achieving the target of 16 freezable embryos in the first flush, a further $1 / 10$ after the second flush and $1 / 4$ after the third.

Since $1987 \approx 2000$ embryos have been transferred (see table III). In addition, a further $2.5 \%$ of all embryos transferred were either lost at the point of transfer, or were considered unsuitable. In the foundation phase, transfers were usually made in 2 discrete sessions. In 1987, essentially all transfers were performed surgically, while all of those in 1990 have been nonsurgical. In 1988 and 1989, all were nonsurgical, except for $\approx 100$ in each year, conducted to compare the performance of the 2 techniques. Essentially all transfers were to Hereford $x$ Friesians, mostly heifers. In most case, oestrus in donors and recipients were matched to within plus or minus $12 \mathrm{~h}$.
Apart from slightly poorer performance in 1988, the pregnancy rates obtained were as expected for commercial embryo transfer in the United Kingdom using frozen embryos. Over the $4 \mathrm{yr}$, from $>2000$ embryos transferred, the overall pregnancy rate has been $60.5 \%$. Between pregnancy diagnosis and calving there appear to be losses of $\approx 5 \%$.

Formal statistical analyses have been undertaken to identify factors having an effect on pregnancy results, on a sample of over 1700 embryos. Significant differences in pregnancy rates were observed between surgical and non-surgical transfers, between grades of embryo as assessed at either freezing or thawing, and between stage of development of the embryo. Details of these analyses will be presented elsewhere.

\section{FAMILY SIZES AND PRODUCTION INFORMATION}

In the foundation phase of the project, the target family size was 8 full sisters. No additional genetic relationships were assumed, although there are also groups of half sisters in the herd. From approximately 1500 embryos transferred over the first $3 \mathrm{yr}$ of the programme, the average number of females born alive per embryo transferred has been 0.25 . Thus to achieve an

Table III. Summary of embryo transfers undertaken to establish the Genus MOET nucleus herd.

\begin{tabular}{|c|c|c|c|c|c|c|c|}
\hline & Year & $\begin{array}{r}\text { Embryos } \\
\text { transferred }\end{array}$ & $\begin{array}{c}\text { No of } \\
\text { pregnancies }\end{array}$ & & $\begin{array}{c}\text { Calves } \\
\text { born }\end{array}$ & $\begin{array}{c}\text { Female } \\
\text { calves }\end{array}$ & $\begin{array}{r}\text { Heifers } \\
\text { mated }\end{array}$ \\
\hline 1 & (1987) & 457 & $299(65.4 \%)$ & 281 & (61.5\%) & 149 & 133 \\
\hline 2 & (1988) & 514 & $323(62.8 \%)$ & 286 & $(55.6 \%)$ & 156 & 140 \\
\hline 3 & (1989) & 523 & $287 \quad(54.9 \%)$ & 257 & $7 \quad(49.1 \%)$ & 121 & - \\
\hline 4 & (1990) & 524 & $311 \quad(59.4 \%)$ & & - & - & - \\
\hline
\end{tabular}


average of 8 full sisters, the original target of 32 embryos transferred per mating is appropriate. However, losses between birth and production need to be allowed for.

In the first 2 yr of the programme, we are currently running at slightly less than the target of 8 full sisters. This is due mainly to the transfer of fewer than the planned 32 embryos per mating. In $\mathrm{yr} 1$, there are currently 112 cows milking, from 18 different families, an average of 6.2 per family. Individual families vary in size between 212.

The original plan was to transfer $32 \mathrm{em}$ bryos from each of 16 donors per year. For several reasons this target has proved ambitious. In general, we have used more than 16 new donors each year, usually closer to 20. Where donors fail to make their full contribution of 32 embryos in a particular year, further embryos from that mating have been transferred the following year. In addition to increasing family sizes, this procedure also generates genetic links between successive batches of heifers entering the herd.

The heifers which have calved down have been housed since calving, fed a silage-based complete diet, and milked 3 times a day. Target yields are high, to facilitate the identification of the best cows and the best families in the herd. We now have reasonable numbers of animals which have completed wk 40 (280 days) of lactation, and the expected 305 day average yield is now $>8500 \mathrm{~kg} \mathrm{milk}$, at $4.2 \%$ fat and $3.45 \%$ protein.

Production is recorded automatically at each milking, and composition determined each week. The animals are also classified for type traits and assessed for temperament. Milking speed is recorded automatically, while all veterinary and disease events are noted. Feed intake is being recorded on individual cows during lactation, using an improved version of the system described by Forbes et al (1986).

\section{GENETIC EVALUATION}

Genetic evaluation will be based heavily on performance during the first 3 months of the lactation. In this way, decisions can be made promptly as to which cows are to be used as donors, and these can then be flushed. Those not selected can be got back in calf quickly, without jeopardising the intercalving interval. Selection on part lactation records should not seriously reduce accuracy of selection. According to Wilmink (1987), where animals are reared and managed in the same herd, and treated identically, heritability estimates for production traits obtained over relatively short periods are likely to be similar to those for the whole lactation.

With the extensive information available on cows in the herd, and its family structure, there is considerable potential for implementing relatively sophisticated evaluation procedures. While this is part of our longer-term strategy, methods used to rank cows and MOET families in yr 1 have been relatively simple. These have focussed on a profit (PIN) index, which gives differential emphasis to milk, fat and protein production. Its basic objective is to increase the weight of protein and then fat, but to do so by increasing protein and fat percentages, rather than by simply increasing milk volume.

After ranking them on their PIN values, potential donors were then assessed in terms of type, milking speed and temperament, and animals that were unacceptable on any of these grounds were removed. Approximately one-third of potential donors were discarded.

In the selection phase of the project, the plan is for each of 32 donors to contribute 
16 embryos. With the herd currently at only half its full size, only half of the embryos this year will come from within the nucleus, with the remainder being imported from North America. By 1992, when the nucleus reaches its mature size of 250 cows, all embryos could be produced from within the project. However, as part of the "open nucleus" policy, we will continue to use outside donors.

To date, 20 cows in the nucleus herd have been selected as donors and are being flushed. To date, average embryo production is over 4.5 embryos per flush. Based on the performance of donor cows in US, we anticipate having to flush routinely for 9 months to achieve the target yield of 16 embryos. All of these donors are being mated to imported bulls, although, in time, service sires bred within the MOET project will begin to be used.

\section{CONCLUSION}

The first MOET nucleus breeding programmes with dairy cattle are already in operation. Provided that the technical challenges can be met, MOET schemes have considerable relevance to countries where progeny testing schemes are not possible (McGuirk, 1989). Even in developed countries, MOET schemes offer the possibility of faster rates of genetic progress, due principally to the greater degree of operational control which is possible.
With continuing developments in the reproductive technologies, including the likelihood that we will soon be able to produce large numbers of identical embryos, the potential role of nucleus breeding schemes will be further increased.

Despite these attractions, there are still major challenges to the successful implementation of MOET-based schemes. They will call for high levels of general animal husbandry, and considerable experience and expertise in embryo transfer. The production of large numbers of embryos per donor cow over realistic time periods will pose particular challenges. Over the next few years, the existing MOET breeding schemes will provide valuable first-hand experience on such operational procedures.

\section{REFERENCES}

Colleau JJ, Mocquot JC (1989) Using embryo transfer in cattle breeding. Proc 5th Coll AETE, Lyon 1989, 49-74

Forbes JM, Jackson DA, Johnson CL, Stockhill P, Hoyle BS (1986) Res Dev Agric 3, 175180

McGuirk B (1989) The relevance of MOET programmes to developing countries. Theriogenology 31, 29-40

Nicholas FW, Smith C (1983) Increased rates of genetic change in dairy cattle by embryo transfer and splitting. Anim Prod 36, 341-353

Wilmink $J$ (1987) Efficiency of selection for different cumulative milk, fat and protein yields in first lactation. Livest Prod Sci 17, 211-224 